\title{
TV is the Devil, the Devil is on TV: Wild Religion and Wild Media in South Africa
}

\author{
Lee-Shae S. Scharnick-Udemans \\ lscharnickudemans@uwc.ac.za
}

\section{Abstract}

In keeping with trends in the academy and the rapidly increasing presence, power, and persuasion of digital and electronic media on the African continent and in the global economy, the study of religion and the media in South Africa has become a flourishing field of intellectual inquiry. The expanse of the field in terms of approaches, both methodological and theoretical, demonstrates the multiple and complex interactions between religion and the media in a diverse range of societies and settings. In light of its recent history of apartheid and transition into democracy in the middle 1990s, when paradigmatic constitutional and political changes took place in which the relationship between religion and the media was reconstituted, the South African context, in particular, is ripe for exploring media technology and practices in relation to the political economy of the sacred. This essay pays tribute to David Chidester by testing the possibilities of his theory of 'wild religion' against two vignettes of wild media in South Africa. The first, characterized as $T V$ is the devil explores the apartheid government's pre-emptive religiously saturated ban on television. The second example, described as the devil is on $T V$ assesses viewers' responses to the television program, Lucifer. I argue that when read with Chidester's theorization of the 'wild ambivalence of the sacred', these examples evoke the hitherto under-explored wild character of both religion and the media.

Keywords: wild media, political economy of the sacred, religious diversity, media politics 


\section{Introduction}

In 2008 I had just graduated with an undergraduate degree majoring in Religious Studies and Media from the University of Cape Town. With very little experience but riding the coat tails of the ivy league(ish) credentials that an education from the University of Cape Town provides, I was employed as a research coordinator by a television production company. My job was to provide research support for a children's television program about religion in South Africa. The material I gathered would be used by scriptwriters to create dialogue for the program's main characters. The stars of the show were two puppets, shocking pink Dudu and florescent green Musa. Every Saturday morning, they fulfilled the national broadcaster's mandate to provide nonconfessional educational religious programming to South African audiences. Astonished at my newly minted status as a gainfully employed religious studies graduate, I immediately informed David Chidester, the professor I most wanted to impress. After listening to me relay the absurdities of television production, he referred to the puppets as scholars of religion, and the whole enterprise of public broadcasting and religion as a project of the political economy of the sacred. Thoroughly disturbed and intrigued by Chidester's incisive reading of the new context within which I found myself, I quit my job less than a year later, registered for postgraduate studies, and the rest, as they say, is history.

Chidester has designated a theory of 'wild religion' that has emancipated religion from conventional definitions that are primarily determined by its proximity to 'specialised institutions dealing in transcendence' to a more nuanced understanding of 'religion as an open set of resources and strategies for negotiating a human identity' (Chidester 2012:89). In his estimation, the sacred is produced, not only in opposition to but also in relation to the wild. Both the wild and the sacred remain unstable categories that are defined and redefined in response to the dynamisms of human societies. In his book, written in 2012, he revisits and highlights an enduring question present throughout his work: Who owns the sacred? This question can be further unraveled by asking who holds the authority to determine what is sacred and what is not, under what conditions this authority is dispensed, and what this all could mean for the ways in which religion is defined and for the ways in which the presence of religion is negotiated in religiously diverse societies. 
An exceptionally large and varied corpus of work on the topic of religion and the media has emerged from scholars working within often complementary and sometimes competing disciplines, including media studies, religious studies, cultural anthropology, psychology, political studies, and sociology. The depth and breadth of the literature and research undertaken in relation to religion and the media as an area of sustained scholarly concern and attention, are evidence to the prevalence of these concepts and their complex relationships to each other and to other crucial aspects of human experience. Hackett proposes that adopting the media as a central category of analysis in studies of religion can provide fresh perspectives on many of the core concepts in the social sciences (viz. power, agency, practice, representation, embodiment, identity, citizenship, authority, community, diaspora, transformation, and the making of [religious] subjects/publics/ counter-publics) (Hackett 2014:67).

The adoption of the media as a category of analysis, particularly in a study of religion within the context of a new and emerging nation, provides one with the opportunity to evaluate the history of religion in South Africa through exploring the ways in which religion and the media as categories have been configured within changing socio-political contexts.

Chidester's penchant for the popular is a hallmark of his scholarship. In his 1996 essay, The church of baseball, the fetish of Coca-Cola, and the potlatch of Rock ' $n$ ' Roll', Chidester borrows from a baseball player, an eclectic author who has written books on Coca-Cola and coffee, and a rock critic's interpretation of the 1963 song Louie, Louie, to establish the concepts 'church', 'fetish', and 'potlatch' as theoretical models for the study of religion in American popular culture. While wielding the authority of the popular in an extended exploration of baseball, Coca-Cola, and Rock 'n' Roll, Chidester submits these concepts to theoretically rigorous critique. He does this in order to show their potential and utility for "our understanding of the character of religion, and the ways in which the very term "religion", including its definition, application, and extension, does not in fact belong solely to the academy but is constantly at stake in the exchanges of cultural discourses and practices' (Chidester 1996:745). Furthermore, the article, later expanded in the book, Authentic fakes (Chidester 2005), suggests that popular culture is a valid epistemological site for observing and engaging the ongoing issue of defining religion and its complexity in an increasingly mediatized world. Chidester's 
penchant for the popular, albeit entertaining and memorable, is neither arbitrary nor vacuous.

In acknowledgement of Chidester's invitation to track the sacred through unconventional strategies and resources, following this broad and productive approach to both, the definition of religion, and the location of knowledge about religion, this essay attempts to do three things: It explores 'the wild ambivalence of the sacred', the appearance of the sacred as 'fundamentalisms', as well as its dual dynamics of inclusion and exclusion, and 'exorcism and domestication', especially as it relates to the relationship between religion and television during apartheid and democracy (Chidester 2012:8-9). In light of Chidester's question and provocation, 'Who owns the sacred?', this essay is particularly interested in reflecting on some of the consequences of the media's stake in the ownership of the sacred. In order to pursue this line of analysis, this essay conceptualizes the media's participation in the political economy of the sacred in two ways.

\section{The media and the political economy of the sacred}

The media can be understood to be in conceptual and material opposition to religion. However, the antagonism that this formulation of religion and the media is predicated upon, is not considered static. It is subject to technological, substantive, and contextual shifts that may work to reinforce or contest this arrangement. Furthermore, foregrounding the conflict that plays a role in defining the relationships between religion and the media does not dismiss the position that religion and the media do not necessarily occupy separate theoretical and operational domains, but that they can be viewed as conceptually and organizationally similar and mutually constitutive (Morgan 2011; Stolow 2013). A scholar on religion, media, and technology, Jeremy Stolow, has thoroughly scrutinized the relationship between religion and technology by revising 'the very supposition that religion and technology exist as two ontologically distinct arenas of experience, knowledge, and action' (Stolow 2013:2). As with wild religion, the dialectical dualism that emerges when considering the historical and operational tension between religion and the media is not in need of resolution. Instead, it may be viewed as a productive point of departure for considering the multiple ways in which the political economy of the sacred has been implicated in the political economy of the media. 
Second, the media acts as sites for the production and circulation of images and discourses that contain representations of religious traditions and religious diversity. This conception of the media is supported by a body of scholarship on 'the media politics of religious diversity' (Eisenlohr 2012:37) and encompasses issues related to the representation of images and discourses of religious tradition and religious diversity. However, it also speaks to the ways in which the 'media and media practices are a generative force in producing diversity and its particular shapes' (Eisenlohr 2012:37). Mirroring 'wild religion', wild media operates outside of the control of traditional religious settings and outside of the auspices of traditional figures of authority.

Wild religion in its interaction with wild media is subject to processes of mediatization that are crucial to the operational and ideological character of media technology (Hjarvard 2016). In terms of form and content, religion in the media is constantly defined and redefined by media-makers, users, audiences, and critics. In this way the media, as conduit of information about religion, and in compliance to its institutional norms through the particularity of its modalities of production and circulation, also constitutes a threat to those who consider its generative and interpretative functions in relation to religion as inappropriate (Hjarvard 2016; Meyrowitz 1993). Non-religious media sources and sites are able to portray religion in ways that might challenge traditional or acceptable religious and theological sensibilities in ways that are not necessarily approved of by religious authorities and constituencies. Since the political economy of the media necessarily works to mold religion to meet its institutional modus operandi, wild media presents interpretations of religion that are unpredictable and unauthorized.

\section{Television as the devil}

The National Party government considered television a credible threat to the social order of apartheid. The government's position was underwritten by wild religiopolitical moral discourses and sentiments. Before its introduction, the National Party worked hard to justify the absence of television. The government pleaded poverty - that the state could simply not afford the fiscal strain on the state coffers that would be incurred by introducing a television service. They argued that the country had more pressing matters needing attention and that it would take a lot of work to materially implement separate development for a technology they considered frivolous at the time. However, 
religion, particularly Christianity as interpreted through the lens of Afrikaner nationalism and the Dutch Reformed Church, played a prominent role in bolstering the National Party's anti-television stance to both the members of parliament and the public.

The deeply religious, Christian nationalist approach that the National Party government sought to permeate every facet of life, was crucial to the banning and unbanning of television. Bernard Cros (1996) observes, from the House of Assembly debates from the 1950s to the late 1960s, that television was considered an idol - a god located within the household, with the ability to hypnotize the viewer - thus transgressing the first of the Ten Commandants. Alluding to both the financial and apparently moral cost of a television, a member of the National Party declared in parliament: 'We dare not sell our national soul and that at the high cost of introduction and maintenance of television' (Hansaard 1963:6517). At a time when television was a commonplace commodity in most parts of the world, South African politicians were in the throes of debating whether, in addition to radio, television was in fact necessary (Nixon 1994; Bevan 2008; Krabill 2010).

Television was perilous to the National Party's vision of Afrikaner hegemony. Unlike English programming, which was readily available for purchase, screening, and viewing, programming in Afrikaans was non-existent and would need to be developed from scratch. Its introduction threatened to undermine the hard-won gains made to elevate the status of the Afrikaner language and culture. Television threatened the very basis of the apartheid ideology and policy, and divinely inspired separate development. The government blamed racial mixing in other contexts on the availability of television and sought to protect South Africa from a similar fate. According to Orlick (1970:2),

[a]n official of the Broederbond (a supra-political secret society devoted to the promotion of Afrikaner values) pointed out that although the struggle against Anglicisation from without had been won, the struggle against the enemy from within had just started and must succeed in stopping non-Afrikaner influences based on English and American ways of life which were infiltrating the Union through the radio, cinema, and popular press. 
Therefore, it was prudent for the National Party government to temporarily dismiss the propaganda potential of television and delay the establishment of a television service during the early years of its power. As a result, South Africa would become one of the last countries in the world to introduce a television service.

The moon landing of 1969 represented the proverbial last straw for many white South Africans, with one journalist, echoing the public sentiment, observing that 'the situation is becoming a source of embarrassment for the country' (Cape Times 1969). The National Party, however, remained steadfast in its anti-television position. Although, as popular demand for television increased by the 1960s, in the face of a mounting political opposition and the threat of new technology such as satellites, television's introduction became inevitable.

The parliamentary opposition to the National Party, the United Party (UP), determined that its constituency's desire to be associated with this modern technology was so strong that, as a part of its election campaigns, the UP promised the introduction of a television service. In response, the National Party fortified its opposition, stating that 'inside the pill (of television) there is the bitter poison which will ultimately mean the downfall of civilizations' (Hansaard 1966:5287). The Minister of Post and Telegraphs, Albert Herzog, had declared television, the 'devil's own box for disseminating communism and immorality' (Hansaard 1959:5020). In 1960, Prime Minister Hendrik Verwoerd, in his inaugural address, declared television a 'spiritual danger' and compared it to the physical threat of an atom bomb (Hansaard 1960:3002). The head of the South African Broadcasting Corporation (SABC), Piet Meyer, in contradistinction to television, spoke of radio with the highest esteem, claiming that 'radio distinguishes itself [from television] by the fact that it does not enslave and does not want to enslave the human spirit' (SABC Annual Report 1968:7). Together, Albert Herzog, Hendrik Verwoerd, and Piet Meyer were the anti-television triumvirate (Nixon 1994).

Although perceived as a spiritual danger that sought to undermine the Christian national character of the nation that the apartheid state had labored to construct and maintain, television sets themselves were not banned. According to Herzog, 'There is nothing to prohibit the television as long as the set is not used' (Hansaard 1963:2312). The National Party government was not opposed to the little black box as a material object but worried about what the activation of this device through a television service would mean for the culture 
of apartheid. However, when the development of satellite technology meant that the potential for the transmission and reception of unauthorized viewing was becoming a real threat, the apartheid government coordinated television's transformation from sinful to righteous. With the advent of satellite technology, for those who could not wait on the state to make a decision one way or the other, an aluminum kitchen mixing bowl served as a makeshift satellite dish which could, if weather conditions were favorable, intercept international programs, bringing snowy images and crackling sounds into the home.

Television's transformation from foe to friend was swift. Within two years of the moon landing, the Commission of Inquiry into Matters relating to Television would propose the introduction of a television service. Headed by Piet Meyer, the Commission was widely considered the government's mouthpiece. After the Commission presented its findings, the apartheid government declared that a television service that gave 'direct and unequivocal expression to the established Christian, Western set of norms and values that are valid for South African society in all spheres of life' - which would also 'strengthen and enrich [the] religious and spiritual life' of the nation - would be introduced (Meyer 1971:16). After decades of being at the center of controversy, television was redeemed of its subversive intentions and absolved of its treasonous potential.

The SABC was earmarked as a crucial means for solidifying apartheid and churning out propaganda that would ensure that all South Africans, regardless of race, class, or gender would be subjected to broadcast material that was authorized by the National Party. With the rise of the National Party, the SABC became a government institution, managed by Afrikaner nationalists who interpreted broadcasting policy and instituted broadcasting practice through the lens of apartheid (Meyer 1971). However, the SABC was still bound, at least in principle, to public broadcasting ideals, inspired by John Reith, Director-General of the British Broadcasting Corporation, which dictated that the principles of objectivity and impartiality could only be suspended during times of crisis or war. In 1961, after the Sharpeville Massacre, the head of the SABC shifted the meaning of the term 'crisis' in the broadcasting code to mean hostility toward the republic, essentially providing the SABC with the right to only broadcast material which positively represented the National Party (Hayman \& Tomaselli 1989). The SABC annual report of 1961 justifies this practice: 
Political reports are regarded as contentious and are only broadcast when they are of a factual and/or authoritative nature, or if they consist of a positive policy or statement by a political party represented in Parliament and do not contain comparisons with, or comments on, the declared policy or conduct of other South African political parties (SABC Annual Report 1961:8).

Television broadcasting would be subjected to the same censorship measures as radio. The result was that the 'SABC became the ideological repository of and chief apologist for Apartheid, offering a broadcasting policy characterized by an unabashedly pro-government stance and programming for the white majority' (Mzamane 2006:2).

In analyzing the apartheid government's pre-emptive ban on television, Nixon proposes that censorship and nationalism overlapped in a range of ways that shed light on the various manifestations of political projects and state authority. Following what can be considered a theory of socialidentity formation, Nixon argues that nationalism constructed and articulated group identity primarily around criteria of exclusion. The nexus of nationalism was based on sameness and difference. By the same token, according to Nixon (1994:61), censorship set the specific conditions, under which the permissible was separated from that which was deemed impermissible. In South Africa, Afrikaner nationalism as a political ideology had a complicated liaison with a particular Christian national ethic that was informed and legitimized by the Dutch Reformed Church. The National Party government's suspicion of the new mass medium of television was defined by a basic binary separation of the sacred from the profane, assuming that religion and media technology operated in conflicting domains and were subsequently incompatible.

The religiopolitical character of the National Party located the sacred and perceived threats to it in multiple places. The lines between the state and church were blurred and interchangeable. While it is not within the scope of this paper to explicate the deeply rooted theological underpinnings of apartheid in general, it is evident that religion was used by the National Party to make sense of the absence and subsequent introduction of television to South Africa. In relation to the television question, the wild ambivalence of the sacred can be identified in the wilderness of apartheid religion which saw itself as the bastion of both social order and social ordering through the separate development of races. 
The early history of television in South Africa illustrates how the National Party's attitude towards television was characterized by a suspicion of the technology as cosmologically incompatible with the religiously legitimated political and social order of apartheid. For the apartheid government, the relationship between religion and technology was determined by the view 'that religion and technology can be parcelled out as two discrete dimensions of the cosmos' (Stolow 2012:4). In the case of the apartheid government's pre-emptive ban on television, technology was regarded as more than just technical devices that made communication possible. The essential nature of television technology was considered harmful to the existing social order. The wildness of the media is patent in this example. Between the sacred national values of racial separatism and the profane possibilities of Anglicization and miscegenation that television brought, it was media's potentially destructive attitude towards established values and norms that was emphasized (Orlick 1970). Television was the symbol of the kind of integration that would usurp the Afrikaner as well as their language, religion, and culture of its normative omnipotence in South Africa.

\section{The devil on television}

In January 2016, M-Net, South Africa's subscription-funded television channel, screened the Fox-produced American fantasy police procedural drama, Lucifer. Set in contemporary Los Angeles, Lucifer tells the story of satan on an extended sabbatical from his regular duties as lord of the underworld, experiencing life away from hell. Lucifer is cast as a generically attractive, fashionable, wealthy, thirty-something white male with a British accent, that is apparently an aphrodisiac for every mortal woman he encounters, save for a beautiful but tough and jaded police officer and divorced single mother, Chloe Decker. To give the show a predictably 'unpredictable' twist, Lucifer, in response to the murder of a lover, inserts himself as an unwelcome but useful consultant to the Los Angeles Police Department. In the United States, reviews for the show were mixed. According to one reviewer, '[t]he devil is hot... [but] his cases not so hot' (Slezak 2016). Another reviewer commented: 'Lucifer starts hot, cools quickly' (Slezak 2016; Bianco 2016).

One critic summed up what appears to be the overall consensus: 'Lucifer is as fun and flashy as its promotions have promised. Just don't go into this one expecting anything more extraordinary' (Rawden 2016). Lucifer 
is cast as a typically defiant anti-hero following in the footsteps of the many others in Batman, Daredevil, and Deadpool. Reviewer Chris Cabin (2016) of Slant Magazine made the following scathing comment on the character:

He never does anything that truly suggests a moral complexity beyond an interest in threesomes, jazz piano, and good scotch. The character isn't so much evil, or even a particularly bad person, as he's a showy, attention-hungry douche, the sort of guy who thinks every woman alone at the bar is secretly waiting for him to talk to her.

Reviews aside, the American Family Association in the United States so thoroughly disapproved of the show that it managed to secure a petition of over 140,000 signatories demanding that Lucifer be cancelled, threatening its corporate sponsors with boycotts.

In South Africa, Lucifer was warmly received, but not in a hospitable way. After the screening of the first episode, the dominant headline on news and review sites described the reaction of Christian viewers to the show: 'Lucifer gets viewers fired up' (Ferreira 2016a). An Afrikaans newspaper reported, 'Hel los ná "Lucifer" se eerste episode' (Hell breaks loose after Lucifer's first episode) (Pekeur 2016). Errol Naidoo, a popular evangelical minister and self-proclaimed leader of the 'Christian voice in government and the media', issued an urgent call to subscribers of the Christian lifestyle magazine, Joy. In this call to action, Naidoo implored Christians to stand up for righteousness and to take action against the show by complaining to the Broadcasting Complaints Commission of South Africa (BCCSA) and the Chief Executive Officer of the broadcasting network. Naidoo declared, 'The program is obviously targeted at youth - hence the early broadcast schedule. When the personification of all that is evil is given a positive spin by Hollywood - then you and I must not only pray - but act decisively!' (Naidoo 2016). Whether of their own accord or incited by Naidoo, Christian viewers asserted their right to freedom of religion and to the pursuit of administrative justice by lodging almost one hundred separate complaints - the most ever received by the BCCSA for any broadcast. Below is a selection of the complaints:

It is completely unacceptable to me that an offensive series like Lucifer be televised...I would suggest that DStv contribute to the cultivation of this country and community and not break it down and let it fall into 
$\sin$ - from pornography to Satan worship. It is unacceptable to say the least.

We find the new series Lucifer distasteful. It's being aired in a prime slot in the evening and we feel it promotes Satan as something intriguing which we find offensive. If it must be aired then it should be aired in a late off-peak slot or on the DStv Explora.

DStv is broadcasting this series on Wednesday evening, that actively portrays Satan/Lucifer as a hero to innocent people who might not know better. Has he succeeded in deceiving DStv and South African Christians, to believe that this is an innocent fable as well? In the meantime I cannot support DStv while they are actively spreading Satan's word.

I find it most disturbing that this kind of series is aired during family time (19:00). It goes against any grain of Christianity to project Satan as a caring and helpful 'person'. Children especially will be giving contradicting messages when allowed to watch this. I know one can block it or remove the channel but that is not the point, what has become of morality and values? (Ferreira 2016a).

The registrar of the BCCSA declared the series a bona fide drama and did not prescribe any sanctions for the broadcaster. One BCCSA official reported receiving hate mail after the decision was made public (Abraham 2016). Although the program was not revoked by the broadcasting authority, a barrage of complaints from Christian viewers who threatened to cancel their subscriptions to the channel ensued shortly after the first episode. A new headline emerged: 'M-Net shifts satan to TV hell after Lucifer complaints' (Ferreira 2016b). Within a matter of days, Lucifer was moved from a primetime 19:00 time slot with an age restriction of 13 years, to 23:00 on the least watched day and time slot with an age restriction of 18 , accompanied by no less than three pre-broadcasting warnings. Despite this action on the part of the broadcasters, some Christian viewers were still unsatisfied. A collective of evangelical Christian leaders thanked the broadcaster for the time slot change and the age restriction intervention but felt that this action was not enough to mitigate the potential harm that the program could cause the impressionable youth. This is an extract of their arguments: 
The Lucifer series, whether intentional or not, portrays Satan - the personification of all that is evil - in a sympathetic manner. This is highly dangerous especially to impressionable youth in our nation...The program portrays Satan as a cool and misunderstood individual. Again, whether intentional or not, the impression one gets after viewing the program is that Satan, whom the Bible calls the 'father of lies' is not such a bad guy after all. Lucifer, then, is given a Hollywood makeover and becomes more appealing...We further believe the trendy portrayal of the devil in the 'Lucifer' series will mainstream evil behaviour. The popular media has historically been used to either humanise or dehumanise people to great effect. The 'Lucifer' series humanises the personification of evil to the extent that evil becomes trendy...Evil, or the personification thereof must be strongly condemned and discouraged not positively and sympathetically portrayed in the popular media. We trust that M-Net will put people before profit and will act swiftly to protect our youth from negative and damaging influences on national television in South Africa (Admin 2016).

A number of inferences about the history, politics, and regulation of religion on television in South Africa can be made in response to the complaints, reviews, and replies from the broadcaster regarding the fallout with Lucifer. First, considering the loss of revenue that would be experienced by moving the show to a less lucrative time slot, it could be argued that M-Net's advertising revenue would have less of a fiscal impact than the potential loss of revenue from the cancelled subscriptions of upset Christian viewers. This would not be the first time that a South African corporation has capitulated to the demands of Christian consumers. In 2010, under pressure from Christian groups, retailer Woolworths reversed a decision to remove Christian magazines from the shelf in a matter of days. Commercial power, therefore, is an important factor in religion and public broadcasting.

Second, as evidenced in the complaints, are insights into how South Africans consider the role of television at a national level, as a place for the dissemination of values and morals, and not merely entertainment, echoing a demand for Reithian (cf. John Reith above) ideals, even on subscription television. The opinions of viewers draw attention to the perceived influence of television in South Africa, as the complaints indicate - not only outrage that 
the religiously offensive material was broadcast, but also concern about the perceived purpose and the potential outcomes that screening Lucifer could have on the youth of the country. The complaints underscore the willingness on the part of concerned Christians to engage the media institutions in order to have their religious sensibilities protected and their religious interests advanced. While this example shows that religion is clearly entangled in its authority to regulate broadcasting, it also shows how the media programming has the ability to interpret familiar scripts according to different standards. In the case of Lucifer, religion is mediated through the entertainment agenda of the media. Given the current popular affection for the anti-hero through this interpretation, the ultimate 'bad guy' of evangelical Christianity is represented as not so bad.

\section{Wild religion and wild media}

The reflection of Chidester (2012:88) on fundamentalism as the 'wildest of wild religion' is particularly helpful for making sense on the relationship between and attitudes towards religion and the media, as it has unfurled within the context of the television question in apartheid South Africa and more recently, in the post-apartheid era. The concept of 'fundamentalisms' as suggested by Chidester, is a 'recurring but shifting sign of a crisis of religious authenticity'. He affirms that religiously inspired responses to perceived affronts about the established social order, although a constant feature of the historical landscape, are always 'situational and relational' (Chidester 2012:87-89). The enduring question of 'who owns the sacred' is once again posed, toyed with, and rigorously assessed. As both examples of wild media show, the political economy of the sacred in the media is not only determined by the dynamics of production and circulations which enable the dissemination of images, sounds, and discourses that represent interpretations of religious traditions, religious information, and religious diversity, it is also shaped by the ways that the processes and products produced by the media are engaged and negotiated by the multiple audiences and stakeholders.

As Chidester warns, the situational and relational character of fundamentalism emphasizes the significance of perspective. The National Party government clearly did not consider or care about the effects of its exclusionary religiopolitical policies on all members of the population. Exclusion, through discourses, political policy, and practices, was a feature that 
was necessary to secure the sacred Afrikaner destiny. In general, the religiopolitical policies of apartheid were excellent for the beneficiaries of the system and incomprehensibly bad for those whom the system sought to conquer. For some, apartheid was a sacred social order which conquered the threat of Afrikaner subservience and racial equality, while for others it was a vast wilderness of suppression and oppression. The Christian controversy over Lucifer belies a disregard for freedom of expression as a necessary hallmark of democratic societies and implies a demand for the privileging of Christian sensibilities and sensitivities on the basis of numerical strength, moral superiority, and perhaps even economic power. Like the apartheid government did when they excluded and then strategically introduced television, the desire of these viewers turned critics to exorcise television, quite literally, of the devil, conveying an attempt to domesticate both wild religion and wild media.

\section{Conclusion}

Finally, who owns the sacred? Between puppets, broadcasters, media-makers, policy-makers, politicians, viewers, critics, religious leaders, scholars of religion, scholars of the media, and everyone else, perhaps all of them do - and if they do, then things are bound to get messy. I would, however, venture to argue that, according to Chidester, this might be the point: Wild religion provides us with strategies and resources for understanding the generative chaos that this reality creates. The potential of 'wild religion' for thinking about the political economy of the sacred in the media and for theorizing and evaluating the fluctuations of wild media in contexts of religious diversity and socio-political dynamism lies in its characteristic ambivalence. The strength of Chidester's framing of 'wild' goes beyond its inherent analytical value for considering the definition and position of religion in modern societies. It inspires us, as scholars of religion, to think more expansively and creatively about the field of research as well as the sites thereof. However, in this strength also lies its weakness. Chidester's characteristic narrative style, on the one hand, leaves one intrigued, provoked, and theoretically challenged, yet on the other, leaves one wanting, at least in the methodological sense. How do we study wild religion? If we follow Chidester, we can observe the sacred across time and space through film, literature, political speeches, school curricula, 
heritage sites, news reporting, ethnographic reports, and a host of other locations and sources. The possibilities appear endless. Again, that might be the point.

\section{References}

Abraham, V. 2016. Devil TV series uproar continues with flood of hate mail. Available at: https://www.pressreader.com/south-africa/the-citizenkzn/20160213/281681138929257. (Accessed on 5 December 2018.)

Admin. 2016. Church leaders urge M-Net to cancel Lucifer series. Available at: $\quad$ http://gatewaynews.co.za/church-leaders-urge-m-net-to-cancellucifer-series/. (Accessed on 5 December 2018.)

Bevan, C. 2008. Putting up screens: A history of television in South Africa, 1929-1976. Master's dissertation, University of Pretoria, Pretoria.

Bianco, R. 2016. Review: Lucifer starts hot, quickly cools. Available at: http://www.usatoday.com/story/life/tv/columnist/2016/01/24/reviewlucifer-startshot-quickly-cools/79117832/. (Accessed on 22 June 2016.) Cabin, C. 2016. Lucifer: Season one. Available at: http://www.slantmagazine. com/tv/review/lucifer-season-one. (Accessed on 22 June 2016.)

Cape Times. 1969. Television on the horizon? Cape Town: Argus Press.

Chidester, D. 1996. The church of baseball, the fetish of Coca-Cola, and the potlatch of Rock ' $n$ ' Roll: Theoretical models for the study of religion in American popular culture. Journal of the American Academy of Religion 64, 4: 743-765.

Chidester, D. 2005. Authentic fakes: Religion and American popular culture. Berkeley, Los Angeles: University of California Press.

Chidester, D. 2012. Wild religion: Tracking the sacred in South Africa. Berkeley, Los Angeles, London: University of California Press.

Cros, B. 1996. Why South Africa's television is only twenty years old: Debating civilisation, 1958-1969. Trade Winds 12: 118-129.

Eisenlohr, P. 2012. Media and religious diversity. Annual Review of Anthropology 41: 37-55.

Ferreira, T. 2016a. Lucifer gets viewers fired up. Available at: https://www.channel24.co.za/TV/News/lucifer-gets-viewers-fired-up$\underline{20160210}$. (Accessed on 22 June 2016.) 
Ferreira, T. 2016b. M-Net shifts satan to TV hell after Lucifer complaints. Available at: http://www.channel24.co.za/TV/News/m-net-shifts-satanto-tv-hell-after-lucifercomplaints-20160202. (Accessed on 22 June 2016.)

Hackett, R.I.J. 2014. Interview: Rosalind Hackett reflects on religious media in Africa. Social Compass 61, 10: 67-72.

Hansaard. 1959. Hansaard 101: Union of South Africa, col 5020. Pretoria: Government Printers.

Hansaard. 1960. Hansaard 104: Union of South Africa, cols 2983-3030. Pretoria: Government Printers.

Hansaard. 1963. Hansaard 7: Republic of South Africa, cols 2312-2315. Pretoria: Government Printers.

Hansaard. 1966. Hansaard 18: Republic of South Africa, cols 5287-5290. Pretoria: Government Printers.

Hjarvard, S. 2016. Mediatization and the changing authority of religion. Media, Culture \& Society 38, 1: 8-17.

Hayman, G. \& R. Tomaselli. 1989. Ideology and technology in the growth of South African broadcasting, 1924-1971. In Tomaselli, R., K. Tomaselli \& J. Muller (eds.): Currents of power: State broadcasting in South Africa. Bellville: Anthropos.

Krabill, R. 2010. Starring Mandela and Cosby: Media and the end(s) of apartheid. Chicago: University of Chicago Press.

Meyer, P. 1971. Report of the commission of inquiry into matters relating to television. Pretoria: Government Publications.

Meyrowitz, J. 1993. Images of media: Hidden ferment - and harmony - in the field. Journal of Communication 43, 3: 55-66.

Morgan, D. 2011. Mediation or mediatisation: The history of media in the study of religion. Culture and Religion 12, 2: 137-152.

Mzamane, M. 2006. Celebrating thirty years of television in South Africa. Available at: http://www.tvsa.co.za/user/blogs/viewblogpost.aspx? blogpostid $=10908$. (Accessed on 27 July 2016.)

Naidoo, E. 2016. Urgent!!! Raise up a standard of righteousness in South Africa. Available at: http://www.joydigitalmag.com/news/urgent-raiseup-a-standard-of-righteousness-in-sa/. (Accessed on 5 December 2018.)

Nixon, R. 1994. Homelands, Harlem, and Hollywood: South African culture and the world beyond. New York: Routledge. 
Orlick, P.B. 1970. South Africa: How long without TV? Journal of Broadcasting and Electronic Media 14, 2: 245-258.

Pekeur, S. 2016. Hel los ná 'Lucifer' se eerste episode. Son, 11 February 2016. Available at: https://www.son.co.za/Alles-wat-mal-is/Gossip/hel-losna-lucifer-se-eerste-episode-20160210. (Accessed on 22 June 2016.)

Rawden, J. 2016. Lucifer review: Fox new series is fun and flashy. Available at: http://www.cinemablend.com/television/Lucifer-Review-FoxSeries-Fun-Flashy112737.html. (Accessed on 22 June 2016.)

SABC Annual Report. 1961. South African broadcasting corporation annual report 1961. Johannesburg: SABC.

SABC Annual Report. 1968. South African broadcasting corporation annual report 1968. Johannesburg: SABC.

Slezak, M. 2016. Lucifer review: The devil is hot - his cases, not so much. Available at: http://tvline.com/2016/01/25/lucifer-review-fox-dramatom-ellis-devil/. (Accessed on 22 June 2016.)

Stolow, J. (ed.) 2013. Deus in Machina: Religion technology and the things in between. New York: Fordham University Press.

Lee-Shae S. Scharnick-Udemans Desmond Tutu Centre for Religion and Social Justice University of the Western Cape lscharnickudemans@uwc.ac.za 